\title{
PENGARUH PEMBERIAN BERBAGAI MACAM MOL TERHADAP PERTUMBUHAN UBI JALAR (Ipomoea batatas L.) UNTUK BAHAN TANAM
}

\section{Influence Of Various Local Microorganisms on Sweet Potato Growth (Ipomoea batatas L.) for Planting Materials}

\author{
Dendi Muharam ${ }^{1)}$, Hanny Hidayati Nafi' ah ${ }^{1)}$, dan Novriza Sativa ${ }^{1)}$ \\ ${ }^{1)}$ Program Studi Agroteknologi Fakultas Pertanian Universitas Garut \\ Jl. Raya Samarang No.52A, Tarogong Kaler, Kabupaten Garut, Jawa Barat 44151 \\ e-mail: hanny.hidayati@uniga.ac.id
}

\begin{abstract}
Abstrak
Ubi jalar (Ipomoea batatas L.) merupakan salah satu sumber karbohidrat setalah padi, jagung, dan ubi kayu bagi sekelompok penduduk Indonesia. Tanaman ubi jalar ikut memegang peranan penting di dalam posisi lumbung pangan nasional dan sebagai penunjang program diversifikasi pangan. Pemupukan merupakan salah satu usaha untuk meningkatkan produktivitas lahan. Penelitian ini bertujuan untuk mengetahui mempelajari sejauh mana pengaruh pemberian pupuk cair Mol terhadap pertumbuhan ubi jalar. Penelitian dilakukan di Desa Pasanggrahan, Kecamatan Pukaweing, Kabupaten Garut pada Bulan februari sampai April 2020. Penelitian ini menggunakan Rancangan Acak Kelompok Sederhana (RAK) dengan 10 perlakuan dan tiga ulangan. Perlakuan yang ditempatkan yaitu A. Kontrol Pupuk Gandasil D konsentrasi $0.003 \%$ (30 gram) B. Mol Bonggol Pisang konsentrasi $0.05 \%$ (500 ml ) C. Mol Bonggol pisang konsentrasi $0.075 \%(750 \mathrm{ml}) \mathrm{D}$. Mol Bonggol Pisang konsentrasi $0.1 \%$ (1000 ml) E. Mol Pucuk Labu siam konsentrasi $0.05 \%$ (500 ml ) F. Mol Pucuk Labu siam konsentrasi $0.075 \%(750 \mathrm{ml}) \mathrm{G}$. Mol Pucuk Labu siam konsentrasi $0.1 \%(1000 \mathrm{ml}) \mathrm{H}$. Gandasil D konsentrasi 0.001\% (10 gram) I. Gandasil D konsentrasi 0.002\% (20 gram) J. Gandasil D konsentrasi $0.0025 \%$ (25 gram) . Hasil penelitian menunjukkan signifikan terjadi pengaruh kalium terhadap morfofisiologi ubi jalar pada parameter jumlah setek ubi jalar sedangkan pada parameter panjang sulur utama, jumlah cabang, luas daun, dan bobot kering tanaman tidak signifikan.
\end{abstract}

Kata Kunci : Ubi Jalar, Ipomoea batatas L, MOL, konsentrasi.

\section{Abstract}

Sweet potato (Ipomoea batatas L.) is a carbohydrate source after rice, maize, and cassava for a group of Indonesians. Sweetpotato plants play an important role in the national food barn and support food diversification programs. Fertilization is an effort to increase land productivity. This study aims to determine the effect of using mol liquid fertilizer sweet potatoes' growth. The research was conducted in Pasanggrahan Village, Pukaweing District, Garut Regency, from February to April 2020. This study used a Simple Randomized Block Design (RBD) with ten treatments and three replications. The treatments that were placed were A. Gandasil Fertilizer control D concentration of 
0.003\% (30 grams) B. Banana weevil mol concentration 0.05\% (500 ml) C. Banana weevil mol concentration 0.075\% (750 ml) D. Banana weevil mol concentration $0.1 \%($ $1000 \mathrm{ml})$ E. Mole of Chayote with a concentration of $0.05 \%(500 \mathrm{ml}) \mathrm{F}$. Mol of Top of Chayote with a concentration of $0.075 \%(750 \mathrm{ml}) \mathrm{G}$. Mol of Top of Chayote with concentration of $0.1 \%(1000 \mathrm{ml}) \mathrm{H}$. Gandasil D concentration of $0.001 \%$ ( 10 grams) $\mathrm{I}$. Gandasil D concentration of $0.002 \%$ (20 grams) J. Gandasil D concentration of $0.0025 \%$ (25 grams). The results showed a significant effect of potassium sweet potato morphophysiology on the number of sweet potato cuttings' parameters. In contrast, the parameters of the main tendril length, number of branches, leaf area, and plant dry weight were not significant.

Keywords: Sweet Potatoes, Ipomoea batatas L, MOL, concentration.

\section{Pendahuluan}

Ubi jalar (Ipomoea batatas L.) merupakan salah satu sumber karbohidrat setalah padi, jagung, dan ubi kayu bagi sekelompok penduduk Indonesia. Tanaman ubi jalar ikut memegang peranan penting di dalam posisi lumbung pangan nasional dan sebagai penunjang program diversifikasi pangan (Ginting, 2011). Ubi jalar segar mentah memiliki kandungan gizi $562 \mathrm{~g}$ kalium, $107 \mathrm{mg}$ kalsium, 2,8 protein, kalori 53,00 kal, 5,565 SI vitamin A dan $32 \mathrm{mg}$ vitamin C dalam tiap 100 gram. Setelah dimasak kandungan gizi berkurang menjadi 2,6 mg kalsium, $94 \mathrm{mg}$ kalium, 3.345 SI vitamin A dan $5 \mathrm{mg}$ vitamin C per 100 gram (Suparman, 2006).

Melihat dari kasus para petani ubi jalar, petani kesulitan untuk meningkatkan produktivitas ubi jalar yaitu dalam upaya perbanyakan bibit setek ubi jalar yang kurang untuk dijadikan bahan tanam. Solusi untuk memperbanyak bahan tanam perlu dilakukan perlakuan khusus dalam menigkatkan pertumbuhan batang dan cabang tanaman ubi jalar (Sasongko, 2009).

Salah satu cara untuk meningkatkan pertumbuhan vegetarif tanaman ubi jalar adalah dengan pemberian Mikroorganisme Lokal (MOL). Larutan MOL merupakan larutan hasil fermentasi yang berbahan dasar dari berbagai sumber daya yang tersedia di alam seperti bonggol pisang, maja, lamtoro. Larutan MOL mengandung unsur hara makro (N, $\mathrm{P}, \mathrm{K}, \mathrm{Ca}, \mathrm{Mg}$, dan $\mathrm{S}$ ) dengan andungan unsur hara makro sebesar Nitrogen $0.253 \%$ Posfor $0.167 \%$ dan Kalium $0.037 \%$ dan unsur hara mikro berupa $\mathrm{Zn}, \mathrm{Cu}, \mathrm{Mo}, \mathrm{Co}, \mathrm{B}$, Mn, dan Fe (Syaifudin et.al., 2010; Lampongbulan, at., al 2017). Selain itu larutan MOL mengandung bakteri yang berpotensi sebagai perombak bahan organik, perangsang pertumbuhan, dan sebagai agen pengendali hama dan penyakit tanaman. Mikroorganisme yang ada sangat berguna bagi tanaman seperti: Azospirillum, Azotobacter, Bacillus, Aeromonas, Apergillus, mikroba pelarut fospat dan mikroba selulotik (Syariefa et.al, 2012; Syaifudin et.al, 2010).

Bahan utama dalam pembuatan larutan MOL terdiri dari 3 jenis komponen, antara lain: karbohidrat yang berasal dari cucian beras, glukosa yang berasal dari cairan gula merah, sumber bakteri yang bersal dari sisa-sisa tanaman (Sapareng, 2016). MOL bonggol pisang mengandung zat pengatur tumbuh giberelin dan sitokinin. Tidak hanya itu MOL 
bonggol pisang juga tetap digunakan untuk dekomposer atau mempercepat proses pengomposan sehingga MOL bonggol pisang mampu meningkatkan kualitas kompos (Maspray, 2012; Wanapat, 2001).

Selain MOL bonggol pisang, MOL dari pucuk labu siam juga memiliki kandungan organik dan giberelin yang tingg. Larutan MOL pucuk labu siam mengandung mikroorganisme yaitu Azosprillium sp, Aspergillus nigger dan azotobacter yang sangat penting untuk membantu pertumbuhan tanaman dan berfungsi untuk memperbaki perakaran sehingga mempengaruhi penyerapan hara. (Trubuz, 2012).

Larutan MOL pucuk labu siam dapat digunakan sebagai perangsang pertumbuhan pada fase vegetatif. Selain dari larutan MOL bonggol pisang dan labu siam pemakaian pupuk organik yang dikombinasikan dengan MOL ini dapat menghemat penggunanan pupuk kimia yang hanya mencapai $400 \mathrm{~kg}$ per musim tanam pada $1 \mathrm{Ha}$ sawah (Panudju, 2011). Hasil penelitian Ismaya (2014) pemberian MOL dengan dosis $75 \mathrm{cc} 1 \mathrm{~L}$ air memberikan pertumbuhan vegetatif pada tanaman ubi jalar. Hal ini disebabkan unsur hara yang dibutuhkan tanaman tersedia sehingga dapat merangsang dan mempercepat pertambahan tinggi tanaman, jumlah daun dan jumlah tunas.

Dari beberapa manfaat MOL yang telah dipaparkan maka, peneliti mencoba untuk meneliti mengenai Pengaruh Pemberian Berbagai Macam MOL bonggol pisang dan MOL pucuk labu siam terhadap pertumbuhan ubi jalar untuk bahan tanam.

\section{Metodologi}

\section{Waktu dan Tempat}

Penelitian ini dilaksanakan pada bulan Februari sampai April 2020 di Desa Pasanggrahan J1. Raya Sukawening, Kecamatan Sukawening Kabupaten Garut berada pada ketinggian 795 meter di atas permukaan laut (mdpl) dengan rata-rata curah hujan $1.555,6 \mathrm{~mm} /$ tahun.

\section{Bahan dan Alat Percobaan}

Bahan yang digunakan dalam penelitian ini meliputi stek ubi Jalar Varietas Rancing, polybag ukuran $25 \mathrm{~cm}$ x $25 \mathrm{~cm}$, MOL Bonggol Pisang, dan MOL pucuk labu siam.

Alat yang digunakan meliputi : peralatan budidaya, ajir, meteran, spidol waterproof, tali rapia, kantong plastik, amplop coklat, timbangan dan kamera.

\section{Metode Penelitan}

Metode yang digunakan dalam penelitian ini adalah metode eksperimental menggunakan Rancangan Acak Kelompok Sederhana (RAK) dengan 10 perlakuan:
A. Kontrol Gandasil D konsentrasi $0.003 \%$
B. Mol Bonggol Pisang konsentrasi $0.05 \%$
C. Mol Bonggol pisang konsentrasi $0.075 \%$
D. Mol Bonggol Pisang konsentrasi $0.1 \%$ 
E. Mol Pucuk Labu siam konsentrasi $0.05 \%$

F. Mol Pucuk Labu siam konsentrasi $0.075 \%$

G. Mol Pucuk Labu siam konsentrasi $0.1 \%$

H. Gandasil D konsentrasi $0.001 \%$

I. Gandasil D konsentrasi $0.002 \%$

J. Gandasil D konsentrasi $0.0025 \%$

Perlakuan diulang sebanyak tiga kali sehingga jumlah plot terdapat 30 plot polybag dengan ukuran polybag $25 \mathrm{~cm} \times 25 \mathrm{~cm}$ dengan jarak tanam $20 \mathrm{~cm} \times 20 \mathrm{~cm}$ dan jarak simpan plot $60 \mathrm{~cm} \times 60 \mathrm{~cm}$ dengan jumlah populasi per plot 6 tanaman dan kode plot $\mathrm{A}$ sampai J. Jumlah tanaman per polybag 1 sehingga jumlah populasi tanaman keseluruhan adalah 180 tanaman.

Pengaplikasian MOL dilakukan dengan cara penyemprotan dengan perbandingan larutan $1: 10$ liter air, larutan semprot dalam satu kali aplikasi dengan berbagai macam konsentrasi sesuai perlakuan menghabiskan \pm 9 liter air dengan keperluan larutan semprot per plot 3 liter air atau $500 \mathrm{ml}$ pertanaman.

\section{Analisis Data}

Untuk mengetahui tingkat perbedaan masing-masing perlakuan, maka dilakukan uji $\mathrm{F}$ dengan kaidah pengambilan keputusan.

$\begin{array}{lll}\text { F hit } & \leq \mathrm{F} 0,05 & =\text { tidak berbeda nyata dan diberi tanda }\left({ }^{\mathrm{ns}}\right) \\ \text { F hit } & \geq \mathrm{F} 0,05 & =\text { berbeda nyata dan diberi tanda }(*)\end{array}$

Apabila $\mathrm{F}$ hitung lebih besar dari $\mathrm{f}$ tabel maka dilakukan uji lanjut duncan pada taraf kesalahan $5 \%$.

\section{Pengamatan}

\section{a. Panjang Sulur Utama (cm)}

Panjang sulur yaitu rata-rata panjang batang yang menyulur atau merambat pada tanaman. Pengamatan ini dari setiap plot dihitung semua dikarnakan satu plot berisi 6 polybag dan pengamatan panjang sulur ini dilakukan pada umur 4 MST sesudah aplikasi yang pertama dan 6 MST sesudah aplikasi yang kedua diukur menggunakan meteran yang dilakukan mulai dari permukaan tanah sampai bagian pucuk tanaman.

\section{b. Jumlah Cabang (tunas yang keluar)}

Pengamatan jumlah cabang diambil dari setiap plot dan dihitung semua tanaman yang sudah diberi tanda percobaan perlakuan. Pengamatan ini menghitung tunas yang keluar di setiap tanaman di lakukan pada umur 4 dan 6 MST yang di nyatakan dalam satuan cabang.

\section{c. Luas Daun $\left(\mathrm{cm}^{2}\right)$}

Luas daun yaitu daun yang diambil dari salah satu tanaman yang didestruktif dari setiap plot percobaan. Pengamatan ini diukur menggunakan metode gravimetric yang dinyatakan dalam satuan $\mathrm{cm}^{2}$. Perhitungan luas daun dilakukan pada daun yang terbuka sempurna. Luas daun dihitung berdasarkan perbandingan berat total kertas Sitompul \& Guritno (1995). Pengamatan ini dilakukan pada umur 8 MST. 


\section{d. Bobot Kering Tanaman (g)}

Bobot kering tanaman adalah bobot tanaman dari satu tanaman yang didestruktif setiap plot percobaan. Bobot kering diperoleh setelah tanaman telah selsai ditimbang untuk luas daun kemudian dimasukan kedalam amplop dan masukan kedalam oven dengan suhu $80^{\circ} \mathrm{C}$ selama 2 x 24 jam atau sampai mencapai kering konstan. Pengamatan dilakukan pada umur 8 MST dinyatakan dalam satuan gram.

\section{e. Banyak Setek yang dihasilkan (setek)}

Pengamatan banyak setek yang dihasilkan diambil dari setiap plot dan dipotong sepanjang $15 \mathrm{~cm}$. Pengamatan ini menghitung hasil setek yang telah dipotong dari setiap tunasan dan lakukan pada umur 9 MST yang di nyatakan dalam satuan cabang.

\section{Hasil Dan Pembahasan}

\section{PENGAMATAN PANJANG SULUR UTAMA $(\mathrm{cm})$}

Hasil anaisis ragam menunjukan tidak ada pengaruh pemberian barbagai MOL terhadap panjang sulur tanaman ubi jalar (Tabel 1). Hal ini diduga karena konsentrasi MOL yang diberikan belum cukup untuk meningkatkan panjang sulur ubi jalar. Perkembangan dan produksi suatu tanaman dapat tumbuh dengan baik maka memerlukan unsur- unsur hara yang cukup di dalam tanah terutama unsur $\mathrm{N}$ karena sangat berperan dalam pertumbuhan vegetative terutama pada panjang sulur tanaman. Menurut Suriadikarta et. al., (2005) unsur $\mathrm{N}$ yang diperlukan ubi jalar adalah sebesar $3.76 \%$. Apabila kekurangan $\mathrm{N}$ dapat berpengaruh pada produksi daun serta pertumbuhan tanaman terhambat sehingga tanaman dapat mengalami kematian.

Tabel 1. Panjang sulur tanaman pada umur 4 dan 6 MST.

\begin{tabular}{llc}
\hline \multirow{2}{*}{ PERLAKUAN } & \multicolumn{2}{c}{ Rata rata (cm) } \\
\hline A. Kontrol Gandasil D konsentrasi 0,003 \% & $17.83 \mathrm{a}$ & $28.33 \mathrm{a}$ \\
B. Mol Bonggol Pisang konsentrasi 0,05\% & $15.83 \mathrm{a}$ & $28.83 \mathrm{a}$ \\
C. Mol Bonggol pisang konsentrasi 0,075\% & $19.55 \mathrm{a}$ & $29.16 \mathrm{a}$ \\
D. Mol Bonggol Pisang konsentrasi 0,1 \% & $18.33 \mathrm{a}$ & $29.39 \mathrm{a}$ \\
E. Mol Pucuk Labu siam konsentrasi 0,05\% & $20.16 \mathrm{a}$ & $31.05 \mathrm{a}$ \\
F. Mol Pucuk Labu siam konsentrasi 0,075 \% & $19.83 \mathrm{a}$ & $31.16 \mathrm{a}$ \\
G. Mol Pucuk Labu siam konsentrasi 0,1\% & $19.94 \mathrm{a}$ & $31.44 \mathrm{a}$ \\
H. Gandasil D konsentrasi 0,001\% & $18.33 \mathrm{a}$ & $31.55 \mathrm{a}$ \\
I. Gandasil D konsentrasi 0,002\% & $19.55 \mathrm{a}$ & $33.77 \mathrm{a}$ \\
J. Gandasil D konsentrasi 0,0025\% & $18.77 \mathrm{a}$ & $33.83 \mathrm{a}$ \\
\hline Ketrangan. Angkang
\end{tabular}

Keterangan : Angka yang diukuti huruf yang sama tidak berbeda nyata menurut uji DMRT taraf kesalahan 5\%

\section{PENGAMATAN JUMLAH CABANG}

Hasil analisis ragam menunjukan tidak ada pengaruh pemberian barbagai MOL terhadap jumlah cabang tanaman ubi jalar (Tabel 2).

Tabel 2. Jumlah Cabang Umur 4 dan 6 MST 


\begin{tabular}{llc}
\hline \multirow{2}{*}{ PERLAKUAN } & \multicolumn{2}{c}{ Tunas yang keluar } \\
\hline A. Kontrol Gandasil D konsentrasi 0,003\% & 4 MST & 6 MST \\
B. Mol Bonggol Pisang konsentrasi 0,05\% & $4.50 \mathrm{a}$ & $7.83 \mathrm{a}$ \\
C. Mol Bonggol pisang konsentrasi 0,075\% & $3.33 \mathrm{a}$ & $9.17 \mathrm{a}$ \\
D. Mol Bonggol Pisang konsentrasi 0,1\% & $4.88 \mathrm{a}$ & $7.42 \mathrm{a}$ \\
E. Mol Pucuk Labu siam konsentrasi 0,05 \% & $3.89 \mathrm{a}$ & $7.37 \mathrm{a}$ \\
F. Mol Pucuk Labu siam konsentrasi 0,075 \% & $5.22 \mathrm{a}$ & $6.89 \mathrm{a}$ \\
G. Mol Pucuk Labu siam konsentrasi 0,1 \% & $3.73 \mathrm{a}$ & $7.20 \mathrm{a}$ \\
H. Gandasil D konsentrasi 0,001\% & $5.05 \mathrm{a}$ & $8.20 \mathrm{a}$ \\
I. Gandasil D konsentrasi 0,002\% & $4.44 \mathrm{a}$ & $7.20 \mathrm{a}$ \\
J. Gandasil D konsentrasi 0,0025\% & $3.94 \mathrm{a}$ & $7.34 \mathrm{a}$ \\
\hline Keterangan : Angk yang diukuti & $3.44 \mathrm{a}$ & $7.61 \mathrm{a}$ \\
\hline
\end{tabular}

Keterangan : Angka yang diukuti huruf yang sama tidak berbeda nyata menurut uji DMRT taraf kesalahan 5\%.

Unsur-unsur hara yang terkandung dalam MOL berperan pada pertumbuhan tanaman ubi jalar namun diduga konentrasi yang diberikan belum cukup untuk meningkatkan jumlah cabang ubi jalar. Santosa (2008), menyebutkan bahwa MOL mengandung unsur $\mathrm{N}$ dan $\mathrm{P}$ yang agak berimbang sangat baik untuk pertumbuhan vegetatif tanaman karena mengandung karbohidrat yang terdapat pada air cucian beras, glukosa pada air kelapa, gula merah dan buah buahan sebagai sumber mikroorganisme. Ibrahim (2002), menambahkan bahwa Nitrogen berfungsi memperbaiki pertumbuhan vegetatif tanaman merangsang pertumbuhan daun dan tunas.

\section{PENGAMATAN LUAS DAUN (cm)}

Hasil analisis ragam menunjukan ada pengaruh pemberian barbagai MOL terhadap luas daun tanaman ubi jalar (Tabel 3). Pengaruh pemberian pemberian berbagai macam MOL terhadap luas daun tanaman ubi jalar menunjukan bahwa perlakuan MOL bonggol pisang taraf $\mathrm{C}$ konsentrasi $0,075 \%$ merupakan perlakuan yang menghasilkan rata-rata tertinggi terhadap parameter luas daun ubi jalar dengan rata-rata $3445.92 \mathrm{~cm}^{2}$. Hasil terbaik dari penelitian ini terjadi karena kandungan Nitrogen $(\mathrm{N})$ yang terdapat pada MOL bonggol pisang yang membantu pertumbuhan daun pada tanaman ubi jalar.

Kurniawati et., al ( 2005) menyatakan bahwa semakin banyak jumlah daun terbentuk maka semakin besar total luas daun, selain itu menunjukan bahwa tanaman ubi jalar memanfaatkan cahaya matahari dengan baik. Hal ini sejalan dengan Sitompul dan Guritno (1995) yang menyatakan laju fotosintesis tanaman di tentukan oleh besarnya luas daun, maka cahaya matahari yang di serap semakin optimal, yang nantinya digunakan untuk meningkatkan laju fotosintesis. Daun dianggap sebagai organ fotosintesis utama, sehingga pengamatan daun sangat diperlukan selain sebagai indikator pertumbuhan juga sebagai data penunjang untuk menjelaskan proses pertumbuhan yang terjadi seperti pada pembentukan biomassa.

Tabel 3. Luas Daun Umur 8 MST.

\begin{tabular}{lcc}
\hline PERLAKUAN & \multicolumn{2}{c}{ Rata-rata $\left(\mathrm{cm}^{2}\right)$} \\
A. Kontrol Gandasil D konsentrasi $0,003 \%$ & 2390.37 & $\mathrm{ab}$
\end{tabular}




\begin{tabular}{lll} 
B. Mol Bonggol Pisang konsentrasi 0,05\% $\%$ & 1370.73 & $\mathrm{a}$ \\
C. Mol Bonggol pisang konsentrasi 0,075 \% & 3445.92 & $\mathrm{~b}$ \\
D. Mol Bonggol Pisang konsentrasi 0,1 \% & 2816.66 & $\mathrm{ab}$ \\
E. Mol Pucuk Labu siam konsentrasi 0,05\% & 2085.18 & $\mathrm{ab}$ \\
F. Mol Pucuk Labu siam konsentrasi 0,075\% & 3344.81 & $\mathrm{~b}$ \\
G. Mol Pucuk Labu siam konsentrasi 0,1 \% & 2683.33 & $\mathrm{ab}$ \\
H. Gandasil D konsentrasi 0,001\% & 1781.70 & $\mathrm{a}$ \\
I. Gandasil D konsentrasi 0,002\% & 2535.18 & $\mathrm{ab}$ \\
J. Gandasil D konsentrasi 0,0025\% & 2077.59 & $\mathrm{a}$ \\
\hline
\end{tabular}

Keterangan : Angka yang diukuti huruf yang sama tidak berbeda nyata menurut uji DMRT taraf kesalahan 5\%

Meningkatnya jumlah daun akan meningkatkan pula laju fotosintesis jika daun-daun yang terbentuk tidak saling menaungi tetapi berfungsi secara optimal sebagai organ fotosintesis. Salisbury \& Ross (1991) menyatakan bahwa kapasitas fotosintesis meningkat dengan bertambahnya jumlah daun pada tanaman. Hal ini disebabkan dengan bertambahnya jumlah daun maka luas bidang penyerapan cahaya akan semakin bertambah pula, dengan asumsi bahwa daun-daun tersebut berperan secara optimal (tidak tertutupi atau terhalangi oleh daun-daun lainnya). Selanjutnya Gardner et., al (1991) menambahkan bahwa semakin tinggi hasil fotosintesis, semakin besar pula penimbunan cadangan makanan yang ditranslokasikan dengan asumsi bahwa faktor lain seperti cahaya, air suhu dan hara dalam keadaan optimal.

\section{PENGAMATAN BOBOT KERING TANAMAN (g)}

Hasil analisis ragam menunjukan tidak ada pengaruh pemberian barbagai MOL (Tabel 4). Hal tersebut dapat dipengaruhi oleh konsentrasi MOL yang belum optimal pada pertambahan bobot tanaman ubi jalar. Sitompul dan guritno (1995) menyatakan bahwa bobot kering tanaman menunjukan banyaknya asimilat yang dapat dihasilkan oleh tanaman. Hal ini sangat berperan sebagai sumber energi pertumbuhan. Selain dari faktor genetik yang mampu menentukan hasil tanaman adalah produksi biomassa dan alokasi fotosintat kebagian yang di panen.

Tabel 4. Bobot Kering Tanaman 8MST.

\begin{tabular}{lcc}
\hline PENGAMATAN & \multicolumn{2}{c}{ Rata-rata (gram) 8 MST } \\
\hline A. Kontrol Gandasil D konsentrasi 0,003\% & 26.88 & $\mathrm{a}$ \\
B. Mol Bonggol Pisang konsentrasi 0,05\% & 15.78 & $\mathrm{a}$ \\
C. Mol Bonggol pisang konsentrasi 0,075\% & 27.30 & $\mathrm{a}$ \\
D. Mol Bonggol Pisang konsentrasi 0,1\% & 19.70 & $\mathrm{a}$ \\
E. Mol Pucuk Labu siam konsentrasi 0,05\% & 18.04 & $\mathrm{a}$ \\
F. Mol Pucuk Labu siam konsentrasi 0,075 \% & 23.49 & $\mathrm{a}$ \\
G. Mol Pucuk Labu siam konsentrasi 0,1 \% & 27.26 & $\mathrm{a}$ \\
H. Gandasil D konsentrasi 0,001\% & 24.05 & $\mathrm{a}$ \\
I. Gandasil D konsentrasi 0,002\% & 24.21 & $\mathrm{a}$ \\
J. Gandasil D konsentrasi 0,0025\% & 17.86 & $\mathrm{a}$ \\
\hline
\end{tabular}

Keterangan : Angka yang diukuti huruf yang sama tidak berbeda nyata menurut uji DMRT taraf kesalahan 5\%. 
Menurut Setianingsih (2009) MOL bonggol pisang memiliki peranan dalam masa pertumbuhan vegetatif tanaman dan tanaman toleran terhadap penyakit. Kadar asam fenolat yang tinggi membantu pengikatan ion-ion $\mathrm{Al}$, $\mathrm{Fe}$ dan $\mathrm{C}$ sehingga mampu membantu ketersediaan $\mathrm{P}$ dalam tanah yang berguna pada proses pembungaan dan pembentukan buah. Begitupun dengan MOL pucuk labu siam peranannya hampir sama dengan MOL bonggol pisang. Faktor - faktor yang menentukan kualitas larutan MOL antara lain media fermentasi, kadar bahan baku atau subtrat, bentuk sifat mikroorganisme yang aktif di dalam proses fermentasi, $\mathrm{pH}$, tempratur, lama fermentai, dan rasio C/N larutan MOL (Hidayat, 2006).

Peningkatan bobot kering tanaman membuktikan bahwa tumbuh kembangnya tanaman semakin baik dengan adanya pemberian pupuk hayati, semakin baik pertumbuhan tanaman maka berat brangkasan juga semakin meningkat. Sebagai mana pendapat menurut Guritno (1995) mengatakan berat kering mencerminkan status nutrisi karena bahan kering tanaman tergantung dari fotosistesis dan respirasi. Menurut Mengel at., al (2001) menyatakan bahwa bila hara makro dalam tanah meningkat maka jumlah yang dapat diabsorpsi oleh tanaman juga akan meningkat disertai dengan pembentukan senyawa-senyawa organik dalam jaringan tanaman.

\section{PENGAMATAN JUMLAH SETEK TANAMAN UBI JALAR (Setek)}

Hasil analisis ragam menunjukkan signifikan atau terjadi pengaruh pemberian berbagai macam MOL terhadap jumlah setek ubi jalar (Tabel 5).

Tabel 5. Jumlah Setek Tanaman Ubi Jalar Umur 9 MST.

\begin{tabular}{lcc}
\hline PERLAKUAN & Rata-rata (setek) 9 MST \\
\hline A. Kontrol Gandasil D konsentrasi 0,003 \% & 30.59 & $\mathrm{c}$ \\
B. Mol Bonggol Pisang konsentrasi 0,05\% & 40.11 & $\mathrm{~d}$ \\
C. Mol Bonggol pisang konsentrasi 0,075\% & 42.00 & $\mathrm{de}$ \\
D. Mol Bonggol Pisang konsentrasi 0,1\% & 45.93 & $\mathrm{fg}$ \\
E. Mol Pucuk Labu siam konsentrasi 0,05\% & 47.94 & $\mathrm{~g}$ \\
F. Mol Pucuk Labu siam konsentrasi 0,075\% & 43.82 & $\mathrm{ef}$ \\
G. Mol Pucuk Labu siam konsentrasi 0,1\% & 19.51 & $\mathrm{a}$ \\
H. Gandasil D konsentrasi 0,001\% & 24.32 & $\mathrm{~b}$ \\
I. Gandasil D konsentrasi 0,002\% & 26.50 & $\mathrm{~b}$ \\
J. Gandasil D konsentrasi 0,0025\% & 24.04 & $\mathrm{~b}$ \\
\hline
\end{tabular}

Keterangan : Angka yang diukuti huruf yang sama tidak berbeda nyata menurut uji DMRT taraf kesalahan 5\%

Perlakuan MOL taraf D konsentrasi $0,1 \%$ dan taraf E konsentrasi 0,05\% memberikan hasil yang lebih baik dari perlakuan lainya, konsentrasi terbaik pada MOL bonggol pisang kisaran $0,75 \%$ - $0,1 \%$ dan konsentrasi terbaik pada MOL pucuk labu siam kisaran $0,05 \%-0,1 \%$. Konsentrasi larutan MOL mempengaruhi pertumbuhan ubi jalar, jika konsentrasi lebih tinggi maka jumlah mikroorganisme yang diberikan kedalam media tanam lebih banyak.

\section{Kesimpulan}


Kesimpulan dari penelitian ini yaitu :

1. Terjadi pengaruh dari beberapa MOL dan konsentrasi terhadap morfosiologi ubi jalar pada parameter pengamatan : jumlah setek ubi jalar.

2. MOL terbaik terdapat pada MOL pucuk labu siam konsentrasi $0.05 \%-0.1 \%$ dan MOL bonggol pisang konsentrasi $0.75 \%-0.1 \%$ dalam meningkatkan pertumbuhan Ubi jalar.

\section{Daftar Pustaka}

Gardner, F., RB Pearce., R. L Mitchell., 1991. Physiology Of Crop Plants (Fisiologi Tanaman Budidaya : Terjemahan Herawati Susilo). Penerbit Universitas Indonesia, Jakarta.

Ginting E., J. Utomo, R. Yulifianti, dan M. Jusuf. 2011. Potensi Ubi Jalar Ungu Sebagai Pangan Fungsional. Jurnal Iptek Tanaman Pangan. Vol. 6. (1).

Hidayat. et al. 2006. Mikrobiologi Umum industri. Yogyakarta: C.V Andi Offiset.

Ibrahim, B. 2002. Integrasi Jenis Tanaman Pohon Leguminosa Dalam Sistem Budidaya Lahan Kering Dan Pengaruhnya Terhadap Sifat Tanah, Erosi dan Produktifitas Lahan. Kimia, Bandung 19-20 0ktober 2009.

Ismaya NR. 2014. Mikroorganisme Lokal (MOL) Buah Pisang Dan Pepaya Terhadap Pertumbuhan Tanaman Ubi Jalar (Ipomoea batatas L). Jurnal. Sekolah tinggi peyuluhan pertanian (STTP). Gowa.

Kurniawati, A., L. K. Darusma, R. Y. Rachmawati. 2005. Pertumbuhan Produksi dan Kandungan triterpenoid Dua jenis prgagang (Centela asiatica L. (Urban) sebagai bahan Obat pada berbagai tingkat naungan. Buletin Agronomi. 33(3): 62-67.

Lampongbulan W, Vanny M.A, Anang W.M. 2017. Analisis Unsur Hara Pupuk Organik Cair Dari Limbah Ikan Mujair (Oreochromis mosambicus) Danau Lindu Dengan Variasi Volume Mikroorganisme Lokal (Mol) Bonggol Pisang. Jurnal Akad Kim.Vol 6 (2) : 92-97.

Maspary, 2012. Apa Kehebatan MOL Bonggol Pisang www.gerbangpertanian.com/2012/05/apa-kehebatan-mol-bonggolpisang.html.

Mengel K, Kirkby EA, Kosegarten H and Appel T. 2001. Principles of Plant Nutrition. 5th Ed, Kluwer Academic Publ. London.

Panudju, T. I. 2011. Pedoman Teknis Pengembangan Rumah Kompos.

Salisbury B. F., C. W. Ross. 1991. Plant physiology. (Fisiologi Tumbuhan : Terjemahan Diah R Lukman dan Sumaryono). Jilid II. Penerbit ITB, Bandung. 
Santosa, E. 2008. Peranan Mikroorganisme Lokal Dalam Budidaya Tanaman Padi Metode Sysytem Of Rice Intesification. Gramedia. Jakarta.

Sapareng S. 2016. Pemanfaatan Limbah Batang Sebagai Sumber Mikroorganisme Lokal (MOL) Untuk Pertumbuhan Dan Produksi Cabe.Jurnal Galung Tropika.Program Studi Agroteknologi. Fakultas Pertanian Universitas Andi Djamma. Palopo Vol.5 (3) : Hal 143 - 150.

Sasongko LA. 2009. Perkembangan Ubi Jalar Dan Peluang Pengembangannya Untuk Mendukung Program Percepatan Diversifikasi Konsumsi Pangan Di Jawa Tengah.Mediaagro. Vol. 5. (1):

Setianingsih, R. 2009. Kajian Pemanfaatan Pupuk Organik Cair Mikro Organisme Lokal (MOL) dalam priming, Umur Bibit dan Peningkatan Daya Hasil Tanaman Padi (Oryza sativa L): Jurnal Agronomi Fakultas Pertanian Universitas Gajah Mada Yogyakarta.

Sitompul, S. M dan B. Guritno.1995. Analisis Pertumbuhan Tanaman Gadjah Mada University pres. Yogyakarta. Hal 38-45.

Suparman. 2006. Bercocok Tanam Ubi Jalar. Azka Press, Bandung.

Suriadikarta, D. A., T. Prihatin, D setyorini dan W. Hartatik 2005. Teknologi Pengolahan Bahan Organik Tanah. Pusat Penelitian dan Pengembangan Tanah dan Agroklimat.

Syaifudin, A., L. Mulyani., dan E. Sulastri. 2010. Pemberdayaan MikroOrganisme Lokal Sebagai Upaya Peningkatan Kemandirian Petani. Karya Tulis.

Syariefa at., al. 2012. Mikroba Juru Masak Tanaman. Depok: PT. Trubus Swadaya

Trubuz. 2012. Mikroba juru masak tanaman. PT. Trubus Swadaya. Depok.

Wanapat, M. 2001. Isolasi dan karakterisai bakteri dan jamur ligno selulotik saluran pencernaan kerbau, kuda dan feses gajah. Teisis. Program studi bioteknlogi. Fakultas antar bidang. Universitas gajah mada. Yogyakart 